Article

\title{
Study on Reaction Characteristics of Chemical-Looping Combustion between Maize Stalk and High Index Facet Iron Oxide
}

\author{
Wu Qin ${ }^{1, *}$, Changfeng Lin ${ }^{1}$, Jianye Wang ${ }^{1}$, Xianbin Xiao ${ }^{1}$, Changqing Dong ${ }^{1}$ and Li Wei ${ }^{2, *}$ \\ 1 National Engineering Laboratory for Biomass Power Generation Equipment, School of Renewable Energy \\ Engineering, North China Electric Power University, Beijing 102206, China; changfenglin163@163.com (C.L.); \\ wjy664432700@163.com (J.W.); xiaoxianbin@ncepu.edu.cn (X.X.); cqdong1@163.com (C.D.) \\ 2 State Key Laboratory of Urban Water Resource and Environment, Harbin Institute of Technology, \\ Harbin 150090, China \\ * Correspondence: qinwugx@126.com (W.Q.); weilihit@126.com (L.W.); Tel./Fax: +86-10-6177-2457 (W.Q.) \\ Academic Editor: Antonio Ficarella \\ Received: 17 June 2016; Accepted: 4 August 2016; Published: 18 August 2016
}

\begin{abstract}
In this work, experiments were performed to investigate the activity and regeneration ability of iron-based oxygen carrier with high index facet (104) during chemical looping combustion (CLC), suggesting that morphological control of the oxygen carrier is very rewarding. $\mathrm{Fe}_{2} \mathrm{O}_{3}(104)$ supported on $\mathrm{Al}_{2} \mathrm{O}_{3}$ was synthesized by a morphology controlled method to undertake maize stalk CLC experiments. Compared with the referenced $\mathrm{Fe}_{2} \mathrm{O}_{3} / \mathrm{Al}_{2} \mathrm{O}_{3}$ prepared by the impregnation method, $\mathrm{Fe}_{2} \mathrm{O}_{3}(104) / \mathrm{Al}_{2} \mathrm{O}_{3}$ presents better reactivity, showing higher fuel conversion rate and $\mathrm{CO}_{2}$ concentration in gaseous products. Further, structural characterizations, including X-ray diffraction (XRD), scanning electron microscopy (SEM) (LEO-1450) and Brunauer-Emmett-Teller (BET) analysis, and multi-cycles CLC reactions were performed to verify the good regeneration and stability of the $\mathrm{Fe}_{2} \mathrm{O}_{3}(104) / \mathrm{Al}_{2} \mathrm{O}_{3}$. The findings indicate that the $\mathrm{Fe}_{2} \mathrm{O}_{3}(104) / \mathrm{Al}_{2} \mathrm{O}_{3}$ is efficient when used for CLC of maize stalk.
\end{abstract}

Keywords: chemical-looping combustion; oxygen carrier; maize stalk; $\mathrm{Fe}_{2} \mathrm{O}_{3}(104)$

\section{Introduction}

Chemical-looping combustion (CLC) is a novel and efficient technology with inherent separation of $\mathrm{CO}_{2}$, thus avoiding extra energy consumption [1,2]. The CLC system is usually composed of two reactors, namely fuel reactor (FR) and air reactor (AR) with oxygen carrier (OC) circulating constantly between them, as shown in Figure 1. In FR, oxygen carrier transfers lattice oxygen to fuel to generate $\mathrm{CO}_{2}$ and $\mathrm{H}_{2} \mathrm{O}$. After condensation of $\mathrm{H}_{2} \mathrm{O}$, a $\mathrm{CO}_{2}$ stream can be obtained. Subsequently, the reduced $\mathrm{OC}$ is transported back to the air reactor (AR) and oxidized by air for the next cycle of reaction.

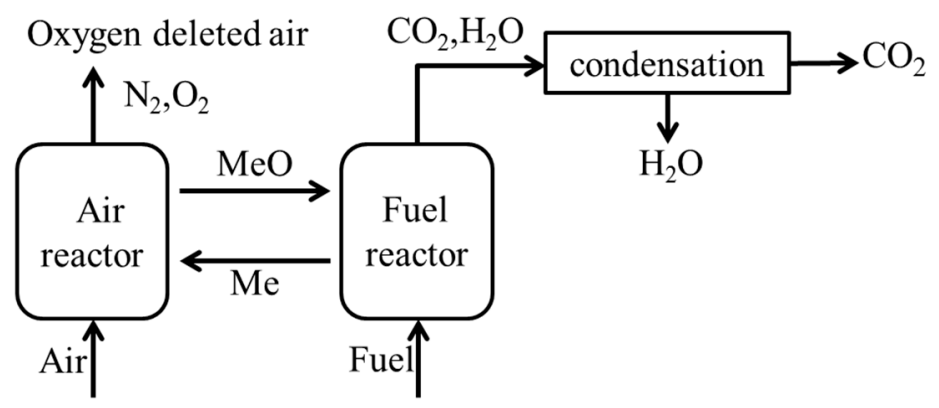

Figure 1. Schematic of chemical-looping combustion. 
In a CLC system, an oxygen carrier is critical to obtain an excellent CLC performance for its vital functions of transferring oxygen and heat. In comparison with $\mathrm{NiO}, \mathrm{CuO}$ et al., $\mathrm{Fe}_{2} \mathrm{O}_{3}$ presents lower redox reactivity, but $\mathrm{Fe}_{2} \mathrm{O}_{3}$ has become an investigation focus due to its advantages of low cost, high thermal stability, good resistance to sulfur [3], and no diauxic environmental pollution [4-6]. $\mathrm{Fe}_{2} \mathrm{O}_{3}$ doped by $\mathrm{Ni}, \mathrm{Cu}$, Co et al., loading $\mathrm{Fe}_{2} \mathrm{O}_{3}$ on inert support material, and combined iron based OCs have received great attentions because of their enhanced reactivity, reduction of carbon deposition, and good regeneration capacity [7-9]. Nevertheless, the high cost of preparing these multi-component iron-based OCs has inhibited their application in large scale CLC processes. Recently, our team has prepared $\mathrm{Fe}_{2} \mathrm{O}_{3}$ mainly closed by high index facet (104) as novel OC, and demonstrated its excellent performance in CLC with lignite theoretically and experimentally, which put forward a new thinking in developing efficient iron based OC in CLC [10].

During past years, extensive studies of CLC of gaseous fuels with iron oxide as OC have been conducted [11,12], and the CLC reaction mechanisms and CLC equipment are relatively clear. In recent years, CLC with solid fuels have received great interests for the rich solid fuel resources [13-18], and the feasibility has been confirmed by many experiments. Biomass direct combustion is thought to be a near zero emission of $\mathrm{CO}_{2}$ model since the $\mathrm{CO}_{2}$ released in combustion had previously been removed from the atmosphere during biomass growth. Consequently, using biomass as fuel in CLC will result in an interesting negative $\mathrm{CO}_{2}$ emission [19], which can greatly contribute to solve the climate change issue. Nevertheless, differing from the gaseous fuel CLC process, the solid fuel CLC process includes complex components of solid fuel [20], various volatile contents, and unknown pyrolysis mechanisms of these different reactants [21-24].

Despite the excellent performance of the $\mathrm{Fe}_{2} \mathrm{O}_{3}(104)$ OC in CLC of lignite in our previous investigation [10], the CLC characteristic of this novel OC directly reacting with biomass is still unclear, which prevents the application of $\mathrm{Fe}_{2} \mathrm{O}_{3}(104) \mathrm{OC}$ in biomass CLC. Thus, it is very important to systematically investigate the reaction characteristic of $\mathrm{Fe}_{2} \mathrm{O}_{3}(104)$ based CLC with biomass as fuel. Since corn is one of the main corps, maize stalk was chosen as fuel in our CLC experiments. Then the $\mathrm{Al}_{2} \mathrm{O}_{3}$-supported $\mathrm{Fe}_{2} \mathrm{O}_{3}(104)$ was synthesized by morphology controlled method to do TGA experiments and FTIR analysis to evaluated its reactivity during maize stalk CLC. Further, CO, as the dominant combustible pyrolysis product of maize stalk $[25,26]$, was selected as the model molecule of pyrolysis product to perform single and multi-cycle thermogravimetric analyzer (TGA) experiments so as to obtain a clear insight into the gas-solid reaction characteristic between pyrolysis products and OC. Moreover, the prepared fresh and re-used OCs were characterized by methods of X-ray Diffraction (XRD), scanning electron microscopy (SEM), Brunauer-Emmett-Teller (BET) analysis. Results demonstrate the high reactivity, efficient oxygen transfer capacity, and good regeneration ability of $\mathrm{Fe}_{2} \mathrm{O}_{3}(104)$ during CLC, which will also provide useful information for developing novel OC and solid fuel CLC.

\section{Experimental Methods}

\subsection{Oxygen Carrier Preparation}

The $\mathrm{Fe}_{2} \mathrm{O}_{3}(104) / \mathrm{Al}_{2} \mathrm{O}_{3}$ (the mass fraction of $\mathrm{Fe}_{2} \mathrm{O}_{3}$ is $60 \mathrm{wt} \%$ ) OC was synthesized by morphology controlled preparation method. $1.13 \mathrm{~g} \mathrm{Al}_{2} \mathrm{O}_{3}, 5.38 \mathrm{~g} \mathrm{FeCl}_{3} \cdot 6 \mathrm{H}_{2} \mathrm{O}, 11.6 \mathrm{~g} \mathrm{NaCl}$, and $10 \mathrm{~mL}$ PEG was sequentially added in $190 \mathrm{~mL}$ distilled water with stirring. During this process, the mixture was heated to $120{ }^{\circ} \mathrm{C}$ and kept for $1 \mathrm{~h}$ by adding $0.2 \mathrm{M} \mathrm{Na}_{2} \mathrm{CO}_{3}$ solution. After an additional $2 \mathrm{~h}$ of continuous stirring, the precipitate was filtered and washed. The filtrate was then dried overnight at $80{ }^{\circ} \mathrm{C}$ for several hours and calcined at $900{ }^{\circ} \mathrm{C}$ for $2 \mathrm{~h}$. Finally, the synthesized $\mathrm{Fe}_{2} \mathrm{O}_{3}(104) / \mathrm{Al}_{2} \mathrm{O}_{3}$ samples were further ground and sieved to $0.1-0.2 \mathrm{~mm}$ for experiments. As a comparison, the referenced $\mathrm{Fe}_{2} \mathrm{O}_{3} / \mathrm{Al}_{2} \mathrm{O}_{3}(60 \mathrm{wt} \%)$ was prepared using the traditional method of impregnation reported in our previous work [27]. 


\subsection{Biomass}

In this work, we chose maize stalk as fuel. After being ground and sieved, the maize stalk sample in the size range of 0.1-0.2 mm was collected and used. The sieved fuel sample was characterized using proximate and ultimate analyses (Vario MACRO cube, Hanau, Germany). Results are listed in Table 1, which show that the volatile content of maize stalk is very high while the fixed carbon content is relatively small.

Table 1. Proximate and ultimate analyses of maize stalk.

\begin{tabular}{cccccccccc}
\hline Analysis Method & \multicolumn{4}{c}{ Proximate Analysis Wad/\% } & \multicolumn{4}{c}{ Ultimate Analysis Wad/\% } \\
\hline Content & Fad & Vad & Aad & Mad & Cad & Had & Oad & Nad & Sad \\
\hline Result & 16.76 & 74.37 & 2.97 & 5.90 & 46.98 & 6.13 & 37.20 & 0.57 & 0.25 \\
\hline
\end{tabular}

Notes: Mad: moisture content of air-dried basis; Vad: volatile matters of air-dried basis; Aad: ash content of air-dried basis; Fad: fixed carbon of air-dried basis.

\subsection{TGA Experiment and Characterization Methods}

The reaction between $\mathrm{Fe}_{2} \mathrm{O}_{3}(104) / \mathrm{Al}_{2} \mathrm{O}_{3}$ and maize stalk at the mass ratio of 10:1 was conducted in a simultaneous TGA (TGq500, PerkinElmer, Boston, MA, USA) under nitrogen atmosphere. The mixture of maize stalk with $\mathrm{Fe}_{2} \mathrm{O}_{3}(104) / \mathrm{Al}_{2} \mathrm{O}_{3}$ was loaded to the ceramic pan of the TGA, and then heated from ambient to $800{ }^{\circ} \mathrm{C}$ at $15{ }^{\circ} \mathrm{C} / \mathrm{min}$ and hold for $10 \mathrm{~min}$ to ensure the sufficient conversion of fuel. The flow rate of $\mathrm{N}_{2}$ was $25 \mathrm{~mL} / \mathrm{min}$ and the total mass of mixture was $10 \mathrm{mg}$. As a comparison, reactions between maize stalk and $\mathrm{Fe}_{2} \mathrm{O}_{3} / \mathrm{Al}_{2} \mathrm{O}_{3}$ as well as $\mathrm{Al}_{2} \mathrm{O}_{3}$ were also performed under the same mass ratio and conditions. Gas phase products distribution emitted from TGA were further analyzed by FTIR spectrometer with the scanning range of 3500-1000 $\mathrm{cm}^{-1}$, and the resolution of $4 \mathrm{~cm}^{-1}$.

The temperature programed TGA experiments for CO (volume fraction of $30 \%$ ) with the synthesized OCs were performed by heating from ambient to $800{ }^{\circ} \mathrm{C}$ with a heating rate of $20^{\circ} \mathrm{C} / \mathrm{min}$, and the mass loss of $\mathrm{OC}$ was recorded. To study the regeneration capacity of $\mathrm{Fe}_{2} \mathrm{O}_{3}(104) / \mathrm{Al}_{2} \mathrm{O}_{3} \mathrm{OC}$, a multi-cycle experiment was conducted at $800{ }^{\circ} \mathrm{C}$ in TGA. Reduction and oxidation time were $15 \mathrm{~min}$ and $10 \mathrm{~min}$, respectively, and between the reduction and oxidation stages, pure $\mathrm{N}_{2}$ was the inlet for 5 min to avoid the mixture of $\mathrm{CO}$ and air.

Furthermore, the fresh and the re-used OC were identified by methods of XRD (D/MAX-RB, Rigaku, Tokyo, Japan), SEM (LEO-1450, Carl Zeiss AG, Oberkochen, Germany), BET analysis (Autosorb-iQ-MP, Quantachrome, Boynton Beach, FL, USA).

\section{Results and Discussion}

\subsection{Reaction Between OCs and Maize Stalk}

TGA experiments between maize stalk and $\mathrm{Fe}_{2} \mathrm{O}_{3}(104) / \mathrm{Al}_{2} \mathrm{O}_{3}$ were conducted to investigate the distinct reaction characteristics. As comparison, the TGA reaction of maize stalk with the referenced $\mathrm{Fe}_{2} \mathrm{O}_{3} / \mathrm{Al}_{2} \mathrm{O}_{3}$, and pyrolysis of maize stalk under the presence of $\mathrm{Al}_{2} \mathrm{O}_{3}$ were also studied for reference. Results of TG and DTG are displayed in Figure 2a,b respectively.

According to the TG curve in Figure 2a, the pyrolysis reaction process between maize stalk and $\mathrm{Al}_{2} \mathrm{O}_{3}$ can be divided into three stages, namely: dehydration step, main pyrolysis step, and slight mass loss step [25]. Below $200{ }^{\circ} \mathrm{C}$, dehydration occurs with $2 \mathrm{wt} \%$ moisture released, and the reason for mass loss larger than value listed in Table 1 can be chalked up to the good hydroscopicity of $\gamma-\mathrm{Al}_{2} \mathrm{O}_{3}$. From $200{ }^{\circ} \mathrm{C}$ to $500{ }^{\circ} \mathrm{C}$, the pyrolysis stage happens, which can be attributed to the series reactions of lignin and cellulose in maize stalk. During this process, large amounts of volatile components emit, resulting in a big mass loss of $6.9 \mathrm{wt} \%$. Meanwhile, this pyrolysis process experiences two distinct stages with characteristic temperatures $T_{\mathrm{m}}$ (the peak temperature in relative to the DTG maximum) around $320^{\circ} \mathrm{C}$ and $450{ }^{\circ} \mathrm{C}$, respectively. Over $500{ }^{\circ} \mathrm{C}$, no obvious mass loss for maize stalk can be 
observed and the remaining weight is $91.9 \mathrm{wt} \%$, which can be assigned to the inert material $\left(\mathrm{Al}_{2} \mathrm{O}_{3}\right)$ and residue of the pyrolysis (such as ash and fixed carbon), consistent to the theoretical mass loss value according to Table 1.

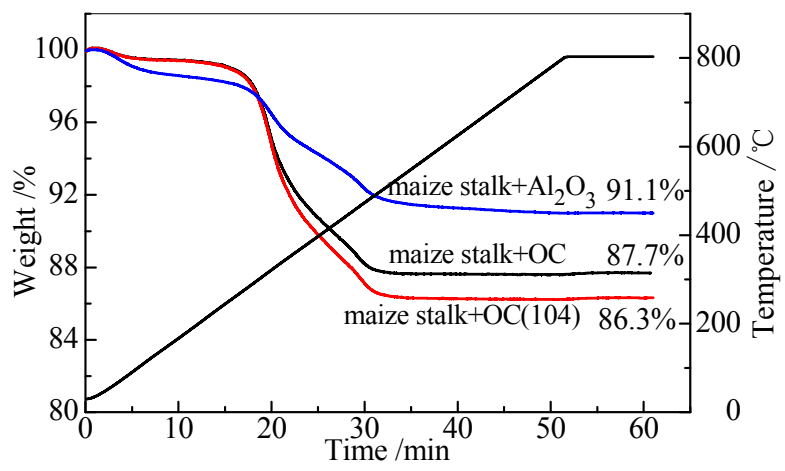

(a)

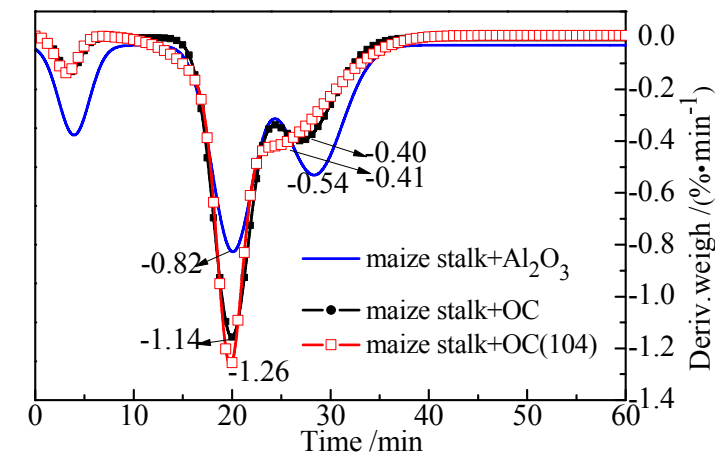

(b)

Figure 2. Thermogravimetric (TG) and differential thermogravimetric (DTG) curves for different samples. (a) TG curves; (b) DTG curves.

Differing from maize stalk pyrolysis, reactions between OCs and maize stalk show larger mass loss with $12.3 \%$ for a (maize stalk $+\mathrm{Fe}_{2} \mathrm{O}_{3} / \mathrm{Al}_{2} \mathrm{O}_{3}$ ) system and $13.7 \%$ for a (maize stalk $+\mathrm{Fe}_{2} \mathrm{O}_{3}(104) / \mathrm{Al}_{2} \mathrm{O}_{3}$ ) system, indicating that OCs promote reactions in TGA. In particular, higher reactivity and oxygen transferring capacity can be obtained by the morphology controlled preparation method. Additionally, the reaction processes with OC also experiences three distinct stages and the mass loss rates are shown in Figure 2b. From Figure 2b, all the second characteristic peaks of these three samples occur around $32{ }^{\circ} \mathrm{C}$, while the mass loss rate for the $\left(\mathrm{Fe}_{2} \mathrm{O}_{3}(104) / \mathrm{Al}_{2} \mathrm{O}_{3}+\right.$ maize stalk) system is $1.26 \mathrm{wt} \% / \mathrm{min}$ larger than the value $(1.14 \mathrm{wt} \% / \mathrm{min})$ for the referenced system $\left(\mathrm{Fe}_{2} \mathrm{O}_{3} / \mathrm{Al}_{2} \mathrm{O}_{3}+\right.$ maize stalk). $\mathrm{Fe}_{2} \mathrm{O}_{3}(104) / \mathrm{Al}_{2} \mathrm{O}_{3}$ presents a higher reactivity than $\mathrm{Fe}_{2} \mathrm{O}_{3}(104) / \mathrm{Al}_{2} \mathrm{O}_{3}$ for maize stalk CLC. As temperature increased, reactivity of OCs increases, which promotes the third $T_{\mathrm{m}}$. Nevertheless, the mass loss rates decrease at the third characteristic $T_{\mathrm{m}}$ after addition of OCs. We speculate that the reaction rate may be limited by the little amount of fuel at the third stage, since larger consumption of the maize stalk happens with the presence of OCs than in the pyrolysis process with $\mathrm{Al}_{2} \mathrm{O}_{3}$ during the second reaction stage. In our previous experiment of CLC with lignite, better performance can also be obtained with $\mathrm{Fe}_{2} \mathrm{O}_{3}(104) / \mathrm{Al}_{2} \mathrm{O}_{3}$ as oxygen carrier [10]. Some experiments suggested that the solid-solid reaction between $\mathrm{Fe}_{2} \mathrm{O}_{3}$ and carbon could occur in TGA at $950{ }^{\circ} \mathrm{C}[28,29]$, whereas in our TGA experiment the mass loss attributed to the solid-solid reaction is negligible in Figure 2a after $30 \mathrm{~min}$ (around $500{ }^{\circ} \mathrm{C}$ ). These may be caused by the lower reaction temperature $\left(800{ }^{\circ} \mathrm{C}\right)$ and the tiny amount of fixed carbon in the mixture.

\subsection{FTIR Analysis}

After the TGA study on the reaction characteristics of maize stalk with $\mathrm{Fe}_{2} \mathrm{O}_{3}(104) / \mathrm{Al}_{2} \mathrm{O}_{3}$ and the referenced $\mathrm{Fe}_{2} \mathrm{O}_{3} / \mathrm{Al}_{2} \mathrm{O}_{3}$, their gaseous products distribution was further detected by FTIR spectrometer so as to gain more fundamental understanding on the related reaction mechanism. FTIR spectra of gaseous products corresponding to the second and third characteristic temperatures for TGA experiments are displayed in Figure 3, with absorbance as $Y$ axis and wavenumber as $X$ axis. According to previous investigations [25,30,31], $2324 \mathrm{~cm}^{-1}, 2143 \mathrm{~cm}^{-1}, 1300-1800 \mathrm{~cm}^{-1}, 3400-3700 \mathrm{~cm}^{-1}$, and 2850-3200 $\mathrm{cm}^{-1}$ refer to the adsorption peak of $\mathrm{CO}_{2}, \mathrm{CO}$, water, and methane, respectively. Besides, according to the monotone increasing functional correlation between concentration of gas and the absorbance, we can present the gas concentration by its absorbance. From Figure 3a, similar gas components can be observed for samples with OCs or $\mathrm{Al}_{2} \mathrm{O}_{3}$, but the addition of OCs results in far larger $\mathrm{CO}_{2}$ absorbance than value for maize stalk pyrolysis. The $\mathrm{CO}_{2}$ absorbance value for the mixture 
with $\mathrm{Fe}_{2} \mathrm{O}_{3}(104) / \mathrm{Al}_{2} \mathrm{O}_{3}(0.019)$ is 2.7 times as large as that for the mixture with $\mathrm{Fe}_{2} \mathrm{O}_{3} / \mathrm{Al}_{2} \mathrm{O}_{3}(0.008)$ and 6 times for maize stalk pyrolysis (0.003). Besides, $\mathrm{CO}$ is detected after adding OCs whereas nearly no $\mathrm{CO}$ can be found in the pyrolysis process of maize stalk. With temperature increase for maize stalk pyrolysis, $\mathrm{CO}$ is mainly caused by cracking and reforming of thermolabile carbonyl and ether groups can be detected, and a slight $\mathrm{CH}_{4}$ peak occurs. The main gas products are $\mathrm{H}_{2} \mathrm{O}, \mathrm{CO}_{2}, \mathrm{CO}$, $\mathrm{CH}_{4}$, and some organics [32]. Comparing the absorbance of $\mathrm{CO}_{2}$ for reactions of these three mixtures, the $\mathrm{CO}_{2}$ peak in sample with $\mathrm{Fe}_{2} \mathrm{O}_{3}(104) / \mathrm{Al}_{2} \mathrm{O}_{3}$ is at the highest, which indicates more $\mathrm{CO}_{2}$ can be generated due to the oxidation of pyrolysis products by $\mathrm{Fe}_{2} \mathrm{O}_{3}(104) / \mathrm{Al}_{2} \mathrm{O}_{3}$. FTIR results suggest that $\mathrm{Fe}_{2} \mathrm{O}_{3}(104) / \mathrm{Al}_{2} \mathrm{O}_{3}$ exhibits better reactivity and effectively improves the $\mathrm{CO}_{2}$ concentration in gas products. As shown in Figure $3 \mathrm{~b}, \mathrm{CO}$ is the dominant combustible pyrolysis product of maize stalk, corresponding to previous investigations $[25,26]$. Therefore, CLC reactions between CO and OCs would be further investigated in the following section in order to obtain a clear insight into the gas-solid reaction.

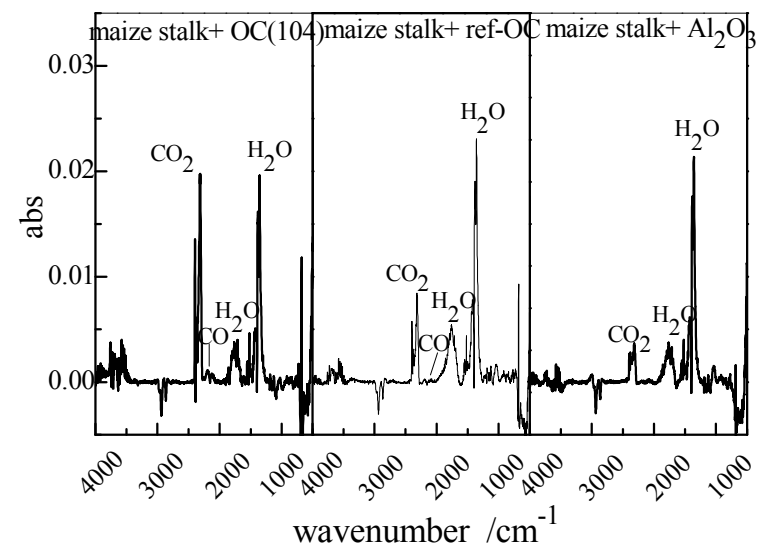

(a)

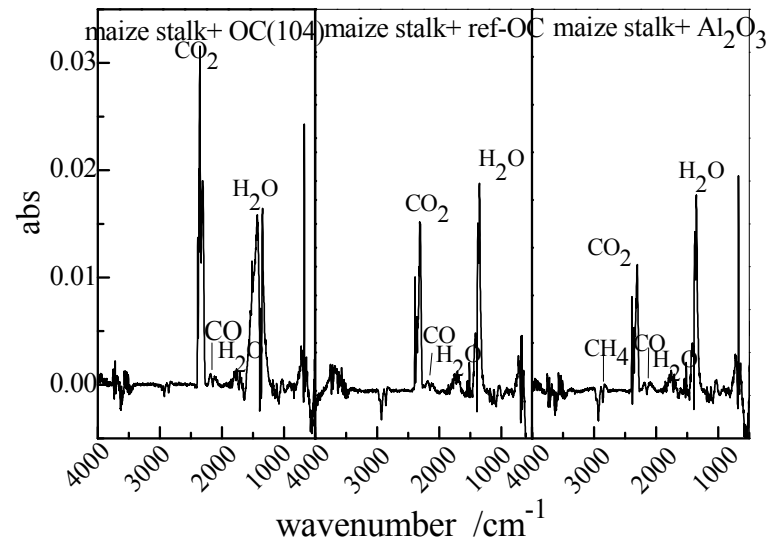

(b)

Figure 3. IR spectra for thermogravimetric experiment gas products of different samples. (a) time corresponding to the second characteristic peaks of TG curves; (b) time corresponding to the third characteristic peaks of TG curves.

\subsection{Reaction between OCs and CO}

To obtain deeper understanding of the reaction characteristic of $\mathrm{Fe}_{2} \mathrm{O}_{3}(104) / \mathrm{Al}_{2} \mathrm{O}_{3}$ with pyrolysis products of maize stalk, we conducted temperature-programmed and isotherm TG experiments between $\mathrm{CO}$ (volume fraction of $30 \%$ ) and $\mathrm{Fe}_{2} \mathrm{O}_{3}(104) / \mathrm{Al}_{2} \mathrm{O}_{3}$ as well as the referenced $\mathrm{Fe}_{2} \mathrm{O}_{3} / \mathrm{Al}_{2} \mathrm{O}_{3}$. Results of the temperature-programmed and isotherm experiments are illustrated in Figure $4 \mathrm{a}, \mathrm{b}$ and Figure 5, respectively. In Figure 4a, reactions between OCs and $\mathrm{CO}$ are initiated from $376{ }^{\circ} \mathrm{C}$. When temperature is below $500{ }^{\circ} \mathrm{C}$, these two TG curves are nearly the same with $\mathrm{Fe}_{2} \mathrm{O}_{3}$ reduction into $\mathrm{Fe}_{3} \mathrm{O}_{4}$. As the temperature increases, reactivity of $\mathrm{Fe}_{2} \mathrm{O}_{3}(104) / \mathrm{Al}_{2} \mathrm{O}_{3}$ improves rapidly with the reduction of $\mathrm{Fe}_{3} \mathrm{O}_{4}$ into $\mathrm{FeO}$ at $32.5 \mathrm{~min}\left(638^{\circ} \mathrm{C}\right)$ and then the further reduction of $\mathrm{FeO}$ into $\mathrm{Fe}$ above $638{ }^{\circ} \mathrm{C}$. When the experiment is terminated, the final mass loss of $14.7 \%$ corresponds to a high conversion degree of $81.7 \%$ for $\mathrm{Fe}_{2} \mathrm{O}_{3}(104) / \mathrm{Al}_{2} \mathrm{O}_{3}$, suggesting that $\mathrm{Fe}_{2} \mathrm{O}_{3}$ is partially reduced into metallic Fe. However, the mass loss rate $\left(2.16 \mathrm{wt} \% / \mathrm{min}\right.$ ) for referenced $\mathrm{Fe}_{2} \mathrm{O}_{3}(104) / \mathrm{Al}_{2} \mathrm{O}_{3}$ (Figure $4 \mathrm{~b}$ ) can be observed, which implies that the reactivity of the referenced $\mathrm{Fe}_{2} \mathrm{O}_{3} / \mathrm{Al}_{2} \mathrm{O}_{3}$ is much lower than that of $\mathrm{Fe}_{2} \mathrm{O}_{3}(104) / \mathrm{Al}_{2} \mathrm{O}_{3}$ with presenting a rather small final mass loss of $4.9 \%$ and reaction rate of $0.85 \mathrm{wt} \% / \mathrm{min}$ in Figure $4 \mathrm{~b}$. The higher conversion degree and reaction rate indicates that $\mathrm{Fe}_{2} \mathrm{O}_{3}(104) / \mathrm{Al}_{2} \mathrm{O}_{3}$ is more active than the referenced $\mathrm{Fe}_{2} \mathrm{O}_{3} / \mathrm{Al}_{2} \mathrm{O}_{3}$ during $\mathrm{CO}$ CLC process when temperature is higher than $500{ }^{\circ} \mathrm{C}$. 


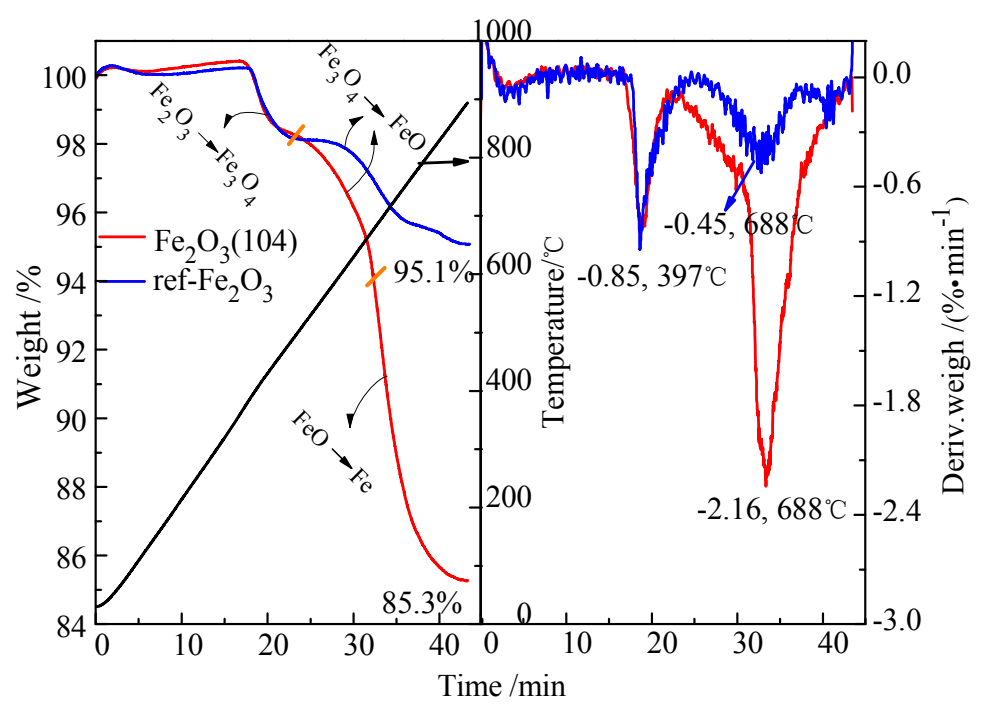

(a)

(b)

Figure 4. TG/DTG curves for reactions between $\mathrm{CO}$ and $\mathrm{Fe}_{2} \mathrm{O}_{3}(104) / \mathrm{Al}_{2} \mathrm{O}_{3}$ or referenced $\mathrm{Fe}_{2} \mathrm{O}_{3} / \mathrm{Al}_{2} \mathrm{O}_{3}$. (a) TG curves; (b) DTG curves.

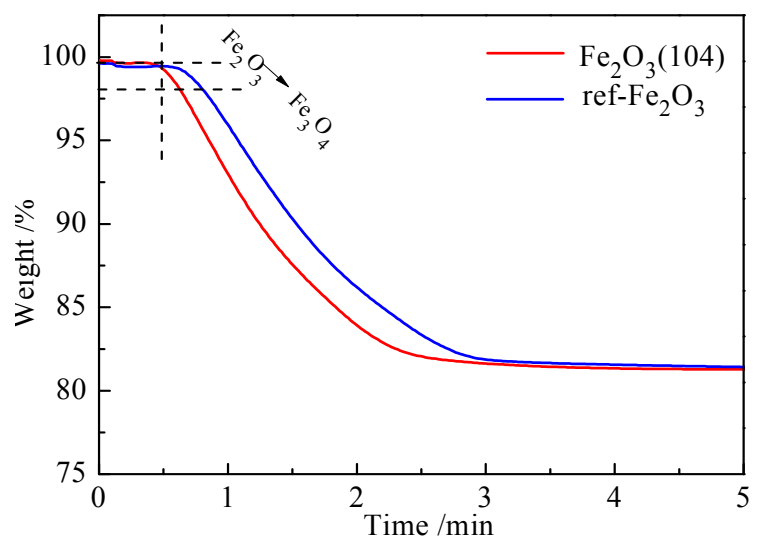

Figure 5. Isotherm thermogravimetric analyzer (TGA) experiments between $\mathrm{CO}$ and $\mathrm{Fe}_{2} \mathrm{O}_{3}(104) / \mathrm{Al}_{2} \mathrm{O}_{3}$ or referenced $\mathrm{Fe}_{2} \mathrm{O}_{3} / \mathrm{Al}_{2} \mathrm{O}_{3}$ at $800{ }^{\circ} \mathrm{C}$.

In addition, previous experiments suggested that the reduction reaction of $\mathrm{Fe}_{2} \mathrm{O}_{3}$ into $\mathrm{Fe}_{3} \mathrm{O}_{4}$ is very fast, while the further reduction reaction from $\mathrm{Fe}_{3} \mathrm{O}_{4}$ to $\mathrm{FeO}$ and even from $\mathrm{FeO}$ to $\mathrm{Fe}$ is much slower $[33,34]$. In this work, despite the promoting effect of temperature increase on OC reactivity, the reaction rate of $\mathrm{Fe}_{2} \mathrm{O}_{3} / \mathrm{Al}_{2} \mathrm{O}_{3}$ at $688^{\circ} \mathrm{C}$ is still lower than that at $397^{\circ} \mathrm{C}$, which suggests the reduction degree of $\mathrm{Fe}_{2} \mathrm{O}_{3}$ is the main reaction rate-determining factor for $\mathrm{Fe}_{2} \mathrm{O}_{3} / \mathrm{Al}_{2} \mathrm{O}_{3} \mathrm{OC}$. Nevertheless, the adverse effect of reduction degree increase of $\mathrm{Fe}_{2} \mathrm{O}_{3}(104) \mathrm{OC}$ on its reactivity is obviously smaller than the promoting effect of temperature increase, which is why the reaction rate of $\mathrm{Fe}_{2} \mathrm{O}_{3}(104) / \mathrm{Al}_{2} \mathrm{O}_{3}$ continues to increase at its high reduction degree. This phenomenon indicates that the $\mathrm{Fe}_{2} \mathrm{O}_{3}(104)$ has better oxygen transfer capacity even at its high reduction degree stage, corresponding to our previous theoretical investigation [35], where the $\mathrm{Fe}_{2} \mathrm{O}_{3}(104)$ surface can be deeply reduced into Fe while the deep reduction of $\mathrm{Fe}_{2} \mathrm{O}_{3}(001)$ is difficult.

Figure 5 illustrates the isotherm TGA results of reaction between OCs and $\mathrm{CO}$ at $800{ }^{\circ} \mathrm{C}$. Both the reactivities of $\mathrm{Fe}_{2} \mathrm{O}_{3}(104) / \mathrm{Al}_{2} \mathrm{O}_{3}$ and the referenced $\mathrm{Fe}_{2} \mathrm{O}_{3} / \mathrm{Al}_{2} \mathrm{O}_{3}$ are greatly enhanced by increasing temperature, and less than $4 \mathrm{~min}$ are consumed for complete reduction of these two OCs under the experiment temperature. In a fluidized system of $\mathrm{CLC}, \mathrm{Fe}_{2} \mathrm{O}_{3} \sim \mathrm{Fe}_{3} \mathrm{O}_{4}$ is commonly used because of its good reactivity and $\mathrm{CO}_{2}$ selection rate [36]. Figure 5 shows the reduction time of $\mathrm{Fe}_{2} \mathrm{O}_{3}$ into $\mathrm{Fe}_{3} \mathrm{O}_{4}$ for 
the high index $\mathrm{OC}$ and the referenced $\mathrm{OC}$ is 9 and $19 \mathrm{~s}$, respectively. Apparently, a faster reaction rate of $\mathrm{Fe}_{2} \mathrm{O}_{3}(104) / \mathrm{Al}_{2} \mathrm{O}_{3}$ can be obtained.

In previous investigations [37,38], the reaction for iron based OCs reduction into $\mathrm{Fe}_{3} \mathrm{O}_{4}$ is very quick (just consuming a few seconds at $950^{\circ} \mathrm{C}$ ). Despite a slightly longer reduction time required in the present work, we should recognize the fact that reaction temperature in our work is only $800{ }^{\circ} \mathrm{C}$ rather than $950{ }^{\circ} \mathrm{C}$ as used in the previous studies. Nonetheless, our prepared OC has very good reactivity. Additionally, our present work preliminarily attempts to apply the morphology controlled method in OC preparation aspect, further detailed properties of such OC obtained via surface-controlled preparation will be discussed in future investigations.

Experiments of OCs with maize stalk and $\mathrm{CO}$ (the dominant combustible pyrolysis component of maize stalk) suggest that the morphology controlled synthesized $\mathrm{Fe}_{2} \mathrm{O}_{3}(104) / \mathrm{Al}_{2} \mathrm{O}_{3}$ is extremely superior in reacting with maize stalk than the referenced $\mathrm{Fe}_{2} \mathrm{O}_{3} / \mathrm{Al}_{2} \mathrm{O}_{3}$. Based on the good reactivity and oxygen transfer capacity of $\mathrm{Fe}_{2} \mathrm{O}_{3}(104) / \mathrm{Al}_{2} \mathrm{O}_{3}$, as well as the CLC system design theorem put forward by Mattisson et al. [39], fewer OC inventory and lower OC transfer flow between the FR and AR will be required if $\mathrm{Fe}_{2} \mathrm{O}_{3}(104) / \mathrm{Al}_{2} \mathrm{O}_{3}$ is adopted as OC.

\subsection{Repeated Cycle Test}

Despite the excellent reactivity and oxygen transfer capacity for $\mathrm{Fe}_{2} \mathrm{O}_{3}(104) / \mathrm{Al}_{2} \mathrm{O}_{3}$ in CLC process with maize stalk and $\mathrm{CO}$, the good regenerativity of OC is still critical to reduce CLC cost. In this section, experiments of multiple redox cycles between $\mathrm{CO}$ and $\mathrm{Fe}_{2} \mathrm{O}_{3}(104) / \mathrm{Al}_{2} \mathrm{O}_{3}$ OC were performed in TGA at $800{ }^{\circ} \mathrm{C}$ to detect the stability of $\mathrm{Fe}_{2} \mathrm{O}_{3}(104) / \mathrm{Al}_{2} \mathrm{O}_{3}$. Results are illustrated in Figure 6 .

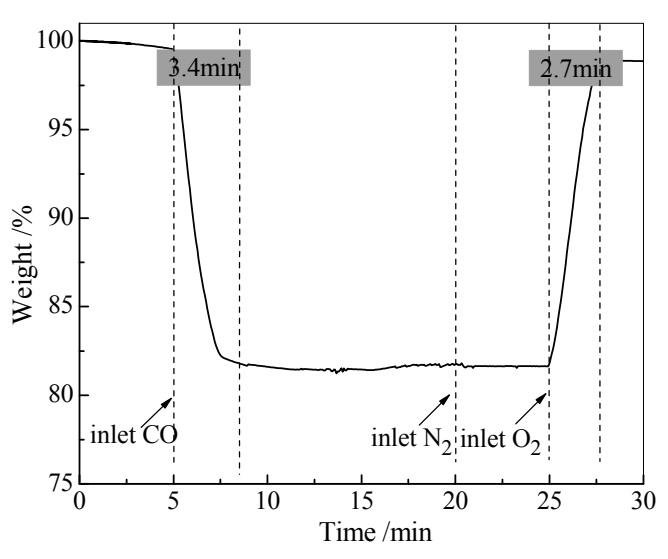

(a)

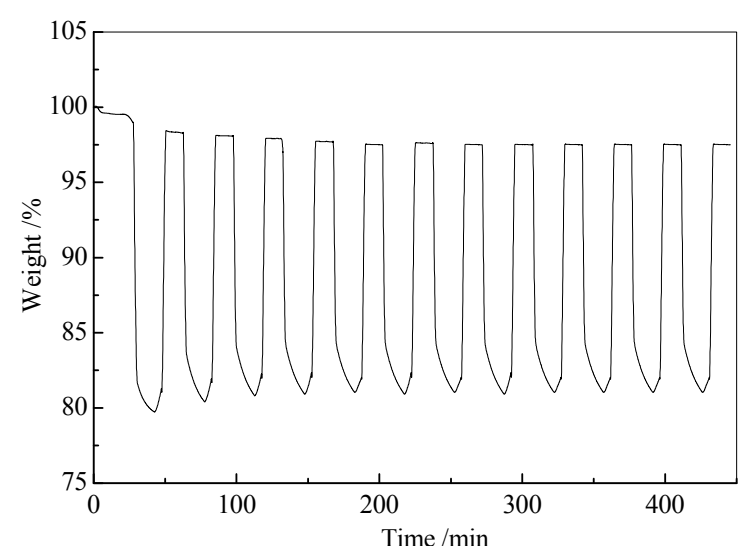

(b)

Figure 6. Redox cycle experiment for chemical looping combustion (CLC) of CO with $\mathrm{Fe}_{2} \mathrm{O}_{3}(104) / \mathrm{Al}_{2} \mathrm{O}_{3}$. (a) one cycle; (b) 12 cycles.

As observed from Figure 6a, the complete reduction time and oxidation time is $3.4 \mathrm{~min}$ and $2.7 \mathrm{~min}$, respectively. Results show that the oxidation rate is greater than the reduction rate [29]. The prepared $\mathrm{Fe}_{2} \mathrm{O}_{3}(104) / \mathrm{Al}_{2} \mathrm{O}_{3}$ is active enough during both reduction and oxidation periods. In Figure $6 \mathrm{~b}$, after the initial three redox cycles, reactivity of OC becomes stable. The total mass loss is $16.51 \%$, which suggests $\mathrm{Fe}_{2} \mathrm{O}_{3}$ is nearly completely reduced by $\mathrm{CO}$. However, the final oxidized mass is stabilized to about $98 \%$ after several cycles. Similar to the reduction reaction mechanism model for iron based OC proposed by Cabello et al. [37], the outer layer of the reduced OC is first oxidize to $\mathrm{Fe}_{2} \mathrm{O}_{3}$ with forming a $\mathrm{Fe}_{2} \mathrm{O}_{3}$ layer, and then oxygen needs to diffuse into inner layer of OC by crossing the $\mathrm{Fe}_{2} \mathrm{O}_{3}$ layer. On the one hand, the investigation suggests that the oxidation process is mainly controlled by diffusional effects in the product layer [40], but on the other hand the large heat released by oxidation of metallic $\mathrm{Fe}$ to $\mathrm{Fe}_{2} \mathrm{O}_{3}$ can cause serious sinter [41] preventing diffusion of oxygen and causing a small amount of the inner $\mathrm{OC}$ (especially close to the interface between the active component and the $\mathrm{Al}_{2} \mathrm{O}_{3}$ 
supporter) which cannot be completely oxidized. Therefore, a slight weight loss of the regenerated OC in Figure 6 occurs. Still, most of the reduced OC is regenerated well and the regenerated OC is covered by $\mathrm{Fe}_{2} \mathrm{O}_{3}$ layer, as confirmed by the following XRD characterization. The multiple redox cycles experiments suggest the good reactivity stability of $\mathrm{Fe}_{2} \mathrm{O}_{3}(104) / \mathrm{Al}_{2} \mathrm{O}_{3}$ and the feasibility of morphological controlled preparation method in OC synthesis process.

To further clarify the stability of $\mathrm{Fe}_{2} \mathrm{O}_{3}(104) / \mathrm{Al}_{2} \mathrm{O}_{3}$, XRD, SEM, and BET analysis of the fresh and regenerated $\mathrm{Fe}_{2} \mathrm{O}_{3}(104) / \mathrm{Al}_{2} \mathrm{O}_{3}$ after 12 cycles are conducted and results are shown in Figure 7 . Figure 7a,b suggest that all the XRD spectrum peaks of $\mathrm{Fe}_{2} \mathrm{O}_{3}$ correspond well with those of $\alpha-\mathrm{Fe}_{2} \mathrm{O}_{3}$ (JCPDS card no. 33-0664), and the diffracted intensity of (104) peak is the strongest which means that the (104) surface is the dominant facet of fresh and regenerated oxygen carrier. The XRD spectrum is consistent to the $\{104\}$ single crystal $\mathrm{Fe}_{2} \mathrm{O}_{3}$ synthesized in previous work of Zhu et al. [42]. Besides, all the narrow peaks, indicates that the crystallinity of synthesized $\mathrm{Fe}_{2} \mathrm{O}_{3}(104) / \mathrm{Al}_{2} \mathrm{O}_{3}$ is well, and no peaks of $\mathrm{Al}_{2} \mathrm{O}_{3}$ can be detected due to the metastable state and amorphous of $\mathrm{Al}_{2} \mathrm{O}_{3}$ formed at $900{ }^{\circ} \mathrm{C}[43,44]$. In comparison with XRD spectrum of the fresh $\mathrm{OC}$, little difference can be found for the regenerated OC in Figure $7 b$, suggesting the well regeneration property of the reduced $\mathrm{Fe}_{2} \mathrm{O}_{3}(104) / \mathrm{Al}_{2} \mathrm{O}_{3}$. Figure $7 \mathrm{c}, \mathrm{d}$ show the SEM pictures of the fresh and regenerated $\mathrm{Fe}_{2} \mathrm{O}_{3}(104) / \mathrm{Al}_{2} \mathrm{O}_{3}$, respectively, where we can observe no significant agglomeration in the morphology. Both of the surface structures in Figure 7c,d are porous and rough with the specific surface areas of around $40 \mathrm{~m}^{2} / \mathrm{g}$. Characterization analysis verifies the good regeneration capacity of $\mathrm{Fe}_{2} \mathrm{O}_{3}(104) / \mathrm{Al}_{2} \mathrm{O}_{3}$.
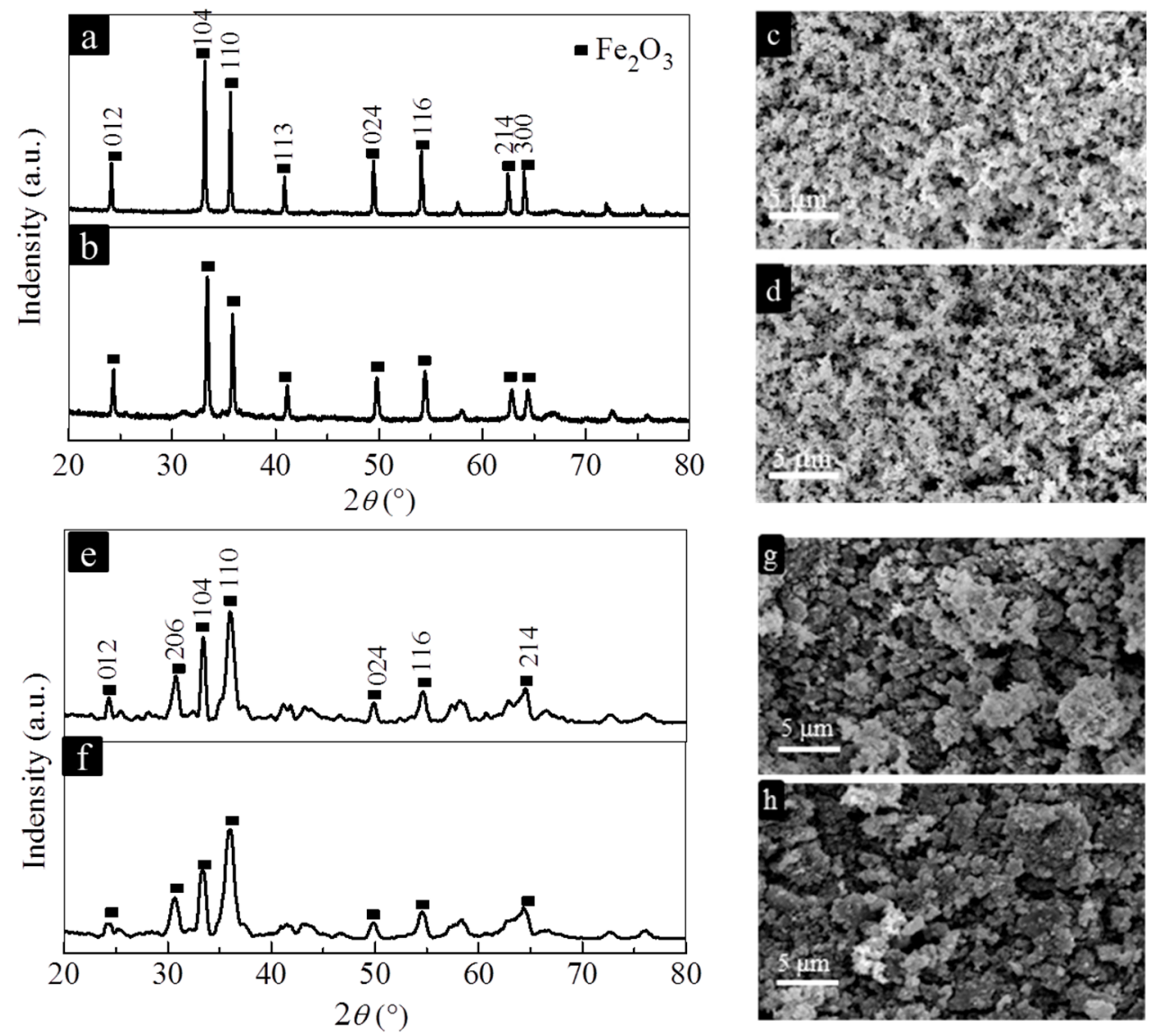

Figure 7. XRD spectrum and SEM pictures of the fresh and the regenerated $\mathrm{Fe}_{2} \mathrm{O}_{3}(104) / \mathrm{Al}_{2} \mathrm{O}_{3}$ and $\mathrm{Fe}_{2} \mathrm{O}_{3} / \mathrm{Al}_{2} \mathrm{O}_{3}$. (a,b) XRD spectrum of the fresh and regenerated $\mathrm{Fe}_{2} \mathrm{O}_{3}(104) / \mathrm{Al}_{2} \mathrm{O}_{3} ;(\mathbf{c}, \mathbf{d}) \mathrm{SEM}$ pictures of the fresh and regenerated $\mathrm{Fe}_{2} \mathrm{O}_{3}(104) / \mathrm{Al}_{2} \mathrm{O}_{3} ;(\mathbf{e}, \mathbf{f})$ XRD spectrum of the fresh and regenerated $\mathrm{Fe}_{2} \mathrm{O}_{3} / \mathrm{Al}_{2} \mathrm{O}_{3} ;(\mathbf{g}, \mathbf{h})$ SEM pictures of the fresh and regenerated $\mathrm{Fe}_{2} \mathrm{O}_{3} / \mathrm{Al}_{2} \mathrm{O}_{3}$. 
For comparison, the XRD spectrum and SEM pictures of the fresh and regenerated $\mathrm{Fe}_{2} \mathrm{O}_{3} / \mathrm{Al}_{2} \mathrm{O}_{3}$ are displayed in Figure 7e-h, respectively. A good regeneration ability can be seen for $\mathrm{Fe}_{2} \mathrm{O}_{3} / \mathrm{Al}_{2} \mathrm{O}_{3}$ as well, and the surface structures of the referenced $\mathrm{OC}$ is porous with a similar specific surface area value to $\mathrm{Fe}_{2} \mathrm{O}_{3}(104) / \mathrm{Al}_{2} \mathrm{O}_{3} \mathrm{OC}$. The similar surface structures of these two OCs suggests that the better reactivity of $\mathrm{Fe}_{2} \mathrm{O}_{3}(104) / \mathrm{Al}_{2} \mathrm{O}_{3}$ is mainly contributed by the high index facet of $\mathrm{Fe}_{2} \mathrm{O}_{3}$.

\section{Conclusions}

TG-FTIR experiments have been conducted to detect the CLC characteristic of maize stalk with $\mathrm{Fe}_{2} \mathrm{O}_{3}(104) / \mathrm{Al}_{2} \mathrm{O}_{3}$ synthesized by the morphology controlled preparation method. $\mathrm{Fe}_{2} \mathrm{O}_{3}(104) / \mathrm{Al}_{2} \mathrm{O}_{3}$ shows higher reactivity than the referenced $\mathrm{Fe}_{2} \mathrm{O}_{3} / \mathrm{Al}_{2} \mathrm{O}_{3}$ synthesized by the impregnation method, leading to higher carbon dioxide concentration in gas phase products. Further, the distinct reaction characteristics of OCs with $\mathrm{CO}$ (the dominant combustible pyrolysis product of maize stalk) and the stability of $\mathrm{Fe}_{2} \mathrm{O}_{3}(104) / \mathrm{Al}_{2} \mathrm{O}_{3}$ were detected. Results show that iron-based OC with high index facet exhibits higher oxygen transfer capacity and excellent renewability compared to the referenced iron-based OC. Morphology controlled preparation can act as an efficient method for developing novel OCs for CLC.

Acknowledgments: The authors wish to thank the Fundamental Research Funds for the Central Universities (2016YQ07, 2014ZD14), National Natural Science Foundation of China (51106051, 51206044, 51476056), and the Project supported by the Funds for Creative Research Groups of China (Grant No. 51121062).

Author Contributions: Wu Qin and Changfeng Lin are equal contributors to the experiments and writing manuscript; the other authors participated in the discussion, and to some extent in the writing and editing of the manuscript.

Conflicts of Interest: The authors declare no conflict of interest.

\section{References}

1. Richter, H.J.; Knoche, K.F. Reversibility of Combustion Processes; Oxford University Press: Washington, DC, USA, 1983; pp. 71-85.

2. Jin, H.G.; Wang, B.Q. Principle of cascading utilization of chemical energy. J. Eng. Thermophys. 2004, 25, 181-184.

3. Cabello, A.; Dueso, C.; García-Labiano, F.; Adánez, J. Performance of a highly reactive impregnated $\mathrm{Fe}_{2} \mathrm{O}_{3} / \mathrm{Al}_{2} \mathrm{O}_{3}$ oxygen carrier with $\mathrm{CH}_{4}$ and $\mathrm{H}_{2} \mathrm{~S}$ in a $500 \mathrm{~W}_{\text {th }}$ CLC unit. Fuel 2014, 121, 117-125. [CrossRef]

4. Abad, A.; Mattisson, T.; Lyngfelt, A.; Johansson, M. The use of iron oxide as oxygen carrier in a chemical-looping reactor. Fuel 2007, 8, 1021-1035. [CrossRef]

5. Hossain, M.M.; Sedor, K.E.; de Lasa, H.I. Co-Ni/ $\mathrm{Al}_{2} \mathrm{O}_{3}$ oxygen carrier for fluidized bed chemical-looping combustion: Desorption kinetics and metal-support interaction. Chem. Eng. Sci. 2007, 62, 5464-5472. [CrossRef]

6. Tang, M.C.; Xu, L.; Fan, M.H. Progress in oxygen carrier development of methane-based chemical-looping reforming: A review. Appl. Energy 2015, 151, 143-156. [CrossRef]

7. Zhu, X.; Li, K.Z.; Wei, Y.G.; Wang, H.; Sun, L.Y. Chemical-looping steam methane reforming over a $\mathrm{CeO}_{2}-\mathrm{Fe}_{2} \mathrm{O}_{3}$ oxygen carrier: Evolution of its structure and reducibility. Energy Fuels 2014, 28, 754-760. [CrossRef]

8. Azimi, G.; Leion, H.; Mattisson, T.; Rydén, M.; Snijkers, F.; Lyngfelt, A. Mn-Fe oxides with support of $\mathrm{MgAl}_{2} \mathrm{O}_{4}, \mathrm{CeO}_{2}, \mathrm{ZrO}_{2}$ and $\mathrm{Y}_{2} \mathrm{O}_{3}-\mathrm{ZrO}_{2}$ for chemical-looping combustion and chemical-looping with oxygen uncoupling. Ind. Eng. Chem. Res. 2014, 53, 10358-10365. [CrossRef]

9. Liu, L.; Zachariah, M.R. Enhanced performance of alkali metal doped $\mathrm{Fe}_{2} \mathrm{O}_{3}$ and $\mathrm{Fe}_{2} \mathrm{O}_{3} / \mathrm{Al}_{2} \mathrm{O}_{3}$ composites as oxygen carrier material in chemical looping combustion. Energy Fuels 2013, 27, 4977-4983. [CrossRef]

10. Qin, W.; Lin, C.F.; Cheng, W.L.; Xiao, X.B. Enhancing the activity of iron based oxygen carrier via surface controlled preparation for lignite chemical-looping combustion. Chem. J. Chin. Univ. 2015, 36, 116-123.

11. Ma, J.; Zhao, H.; Tian, X.; Wei, Y.; Zhang, Y.; Zheng, C. Continuous operation of interconnected fluidized bed reactor for chemical looping combustion of $\mathrm{CH}_{4}$ using hematite as oxygen carrier. Energy Fuels 2015, 29, 3257-3267. [CrossRef] 
12. Hossain, M.M.; de Lasa, H.I. Chemical-looping combustion (CLC) for inherent $\mathrm{CO}_{2}$ separations-A review. Chem. Eng. Sci. 2008, 63, 4433-4451. [CrossRef]

13. Wei, G.; He, F.; Zhao, Z.; Huang, Z.; Zheng, A.; Zhao, K.; Li, H. Performance of Fe-Ni bimetallic oxygen carriers for chemical looping gasification of biomass in a $10 \mathrm{~kW}$ th interconnected circulating fluidized bed reactor. Int. J. Hydrog. Energy 2015, 40, 16021-16032. [CrossRef]

14. Thunman, H.; Lind, F.; Breitholtz, C.; Berguerand, N.; Seemann, M. Using an oxygen-carrier as bed material for combustion of biomass in a 12-MW $\mathrm{MW}_{\text {th }}$ circulating fluidized-bed boiler. Fuel 2013, 113, 300-309. [CrossRef]

15. Lyngfelt, A. Chemical-looping combustion of solid fuels-status of development. Appl. Energy 2014, 113, 1869-1873. [CrossRef]

16. Shen, L.; Wu, J.; Xiao, J. Chemical-looping combustion of biomass in a $10 \mathrm{~kW}_{\text {th }}$ reactor with iron oxide as an oxygen carrier. Energy Fuels 2009, 23, 2498-2505. [CrossRef]

17. Adánez-Rubio, I.; Abad, A.; Gayán, P. Biomass combustion with $\mathrm{CO}_{2}$ capture by chemical looping with oxygen uncoupling (CLOU). Fuel Process. Technol. 2014, 124, 104-114. [CrossRef]

18. Luo, M.; Wang, S.; Wang, L. Experimental investigation of co-combustion of coal and biomass using chemical looping technology. Fuel Process. Technol. 2013, 110, 258-267. [CrossRef]

19. Mendiara, T.; Abad, A.; de Diego, L.F. Biomass combustion in a CLC system using an iron ore as an oxygen carrier. Int. J. Greenh. Gas Control 2013, 19, 322-330. [CrossRef]

20. Wang, P.; Massoudi, M. Slag behavior in gasifiers Part I: Influence of coal properties and gasification conditions. Energies 2013, 6, 784-806. [CrossRef]

21. Leion, H.; Mattisson, T.; Lyngfelt, A. Solid fuels in chemical-looping combustion. Int. J. Greenh. Gas Control 2008, 2, 180-193. [CrossRef]

22. Leion, H.; Jerndal, E.; Steenari, B.M.; Hermansson, S.; Mattisson, T.; Lyngfelt, A. Solid fuels in chemical looping combustion using oxide scale and unprocessed iron ore oxygen carriers. Fuel 2009, 88, 1945-1954. [CrossRef]

23. Dennis, J.S.; Scott, S.A. In situ gasification of a lignite coal and $\mathrm{CO}_{2}$ separation using chemical looping with a Cu-based oxygen carrier. Fuel 2010, 89, 1623-1640. [CrossRef]

24. Dennis, J.S.; Múller, C.R.; Scott, S.A. In situ gasification and $\mathrm{CO}_{2}$ separation using chemical looping with a Cu-based oxygen carrier: Performance with bituminous coals. Fuel 2010, 89, 2353-2364. [CrossRef]

25. Ma, Z.; Chen, D.; Gu, J.; Bao, B.; Zhang, Q. Determination of pyrolysis characteristics and kinetics of palm kernel shell using TGA-FTIR and model-free integral methods. Energy Convers. Manag. 2015, 89, 251-259. [CrossRef]

26. Yang, H.; Yan, R.; Chen, H.; Lee, H.D.; Zheng, C. Characteristics of hemicellulose, cellulose and lignin pyrolysis. Fuel 2007, 86, 1781-1788. [CrossRef]

27. Dong, C.Q.; Liu, X.L.; Qin, W.; Lu, Q.; Wang, X.Q.; Shi, S.M.; Yang, Y.P. Deep reduction behavior of iron oxide and its effect on direct CO oxidation. Appl. Sur. Sci. 2012, 258, 2562-2569. [CrossRef]

28. Mendiara, T.; García-Labiano, F.; Gayan, P.; Abad, A.; de Diego, L.F.; Adanez, J. Evaluation of the use of different coals in chemical looping combustion using a bauxite waste as oxygen carrier. Fuel 2013, 106, 814-826. [CrossRef]

29. Rubel, A.; Liu, K.; Neathery, J.; Taulbee, D. Oxygen carriers for chemical looping combustion of solid fuels. Fuel 2009, 88, 876-884. [CrossRef]

30. Giuntoli, J.; de Jong, W.; Arvelakis, S.; Spliethoff, H.; Verkooijen, A.H.M. Quantitative and kinetic TG-FTIR study of biomass residue pyrolysis: Dry distiller's grains with solubles (DDGS) and chicken manure. J. Anal. Appl. Pyrolysis 2009, 85, 301-312. [CrossRef]

31. Tao, L.; Zhao, G.; Qian, J.; Qin, Y. TG-FTIR characterisation of pyrolysis of waste mixtures of paint and tar slag. J. Hazard. Mater. 2010, 175, 754-761. [CrossRef] [PubMed]

32. Fu, P.; Hu, S.; Xiang, J.; Li, P.; Huang, D.; Jiang, L.; Zhang, A.; Zhang, J. FTIR study of pyrolysis products evolving from typical agricultural residues. J. Anal. Appl. Pyrolysis 2010, 88, 117-123. [CrossRef]

33. Zhang, Y.X.; Doroodchi, E.; Moghtaderi, B. Reduction Kinetics of $\mathrm{Fe}_{2} \mathrm{O}_{3} / \mathrm{Al}_{2} \mathrm{O}_{3}$ by ultralow concentration methane under conditions pertinent to chemical looping combustion. Energy Fuels 2015, 29, 337-345. [CrossRef]

34. Adanez, J.; Abad, A.; Garcia-Labiano, F.; Gayan, P.; de Diego, L.F. Progress in chemical-looping combustion and reforming technologies. Prog. Energy Combust. Sci. 2012, 38, 215-282. [CrossRef] 
35. Qin, W.; Lin, C.F.; Long, D.T.; Xiao, X.B.; Dong, C.Q. Reaction activity and deep reduction reaction mechanism of a high index iron oxide surface in chemical looping combustion. Acta Phys. Chim. Sin. 2015, 31, 667-675.

36. Abad, A.; García-Labiano, F.; de Diego, L.F.; Gayán, P.; Adánez, J. Reduction kinetics of Cu-, Ni-, and Fe-based oxygen carriers using syngas $\left(\mathrm{CO}+\mathrm{H}_{2}\right)$ for chemical-looping combustion. Energy Fuels 2007, 21, 1843-1853. [CrossRef]

37. Cabello, A.; Abad, A.; García-Labiano, F.; Gayán, P.; de Diego, L.F.; Adánez, J. Kinetic determination of a highly reactive impregnated $\mathrm{Fe}_{2} \mathrm{O}_{3} / \mathrm{Al}_{2} \mathrm{O}_{3}$ oxygen carrier for use in gas-fueled chemical looping combustion. Chem. Eng. J. 2014, 258, 265-280. [CrossRef]

38. Abad, A.; Adánez, J.; García-Labiano, F.; de Diego, L.F.; Gayán, P.; Celaya, J. Mapping of the range of operational conditions for $\mathrm{Cu}_{-}, \mathrm{Fe}-$, and $\mathrm{Ni}$-based oxygen carriers in chemical-looping combustion. Chem. Eng. Sci. 2007, 62, 533-549. [CrossRef]

39. Mattisson, T.; Lyngfelt, A.; Cho, P. The use of iron oxide as oxygen carrier in chemical-looping combustion of methane with inherent separation of $\mathrm{CO}_{2}$. Fuel 2001, 80, 1953-1962. [CrossRef]

40. Sun, K.; Ishii, M.; Takahashi, R.; Yagi, J.I. Oxidation Kinetics of Cement-bonded Natural Ilmenite Pellets. ISIJ Int. 1992, 32, 489-495. [CrossRef]

41. Cho, P. Development and Characterisation of Oxygen-Carrier Materials for Chemical-Looping Combustion; Chalmers University of Technology: Göteborg, Sweden, 2005.

42. Liu, X.H.; Zhang, J.; Wu, S.H.; Yang, D.J.; Liu, P.R.; Zhang, H.M.; Wang, S.R.; Yao, X.D.; Zhu, G.S.; Zhao, H.J. Single crystal $\alpha-\mathrm{Fe}_{2} \mathrm{O}_{3}$ with exposed $\{104\}$ facets for high performance gas sensor applications. RSC Adv. 2012, 2, 6178-6184. [CrossRef]

43. Levin, I.; Brandon, D. Metastable alumina polymorphs: Crystal structures and transition sequences. J. Am. Ceram. Soc. 1998, 81, 1995-2012. [CrossRef]

44. Macedo, M.I.F.; Bertran, C.A.; Osawa, C.C. Kinetics of the $\gamma \rightarrow \alpha$-alumina phase transformation by quantitative X-ray diffraction. J. Mater. Sci. 2007, 42, 2830-2836. [CrossRef]

(C) 2016 by the authors; licensee MDPI, Basel, Switzerland. This article is an open access article distributed under the terms and conditions of the Creative Commons Attribution (CC-BY) license (http://creativecommons.org/licenses/by/4.0/). 